\title{
PROTOTIPE PEMBERITAHUAN LOKASI KOORDINAT DARURAT MENGGUNAKAN GPS DAN PULSE SENSOR BERBASIS ARDUINO DAN SMS
}

\author{
Rakhmat Rizki Irawan ${ }^{1)}$ \\ 1) Jurusan Teknik Elektro - Universitas Muhammadiyah Gresik \\ J1. Sumatra 101 Gresik 61121 Jawa Timur, Indonesia \\ Email : hendra.umg@gmail.com
}

\begin{abstract}
ABSTRAK
Prototipe Pemberitahuan Lokasi Koordinat Darurat Menggunakan GPS dan Pulse Sensor Berbasis Arduino dan SMS ini berbasis microcontroller Arduino Nano sebagai pusat pengontrol alat dan pemroses data. Alat ini dapat menampilkan indikator led sensor denyut jantung dan push button untuk manual pengaktifan GPS dan pengiriman SMS pada sim808. Ketika nilai denyut jantung bpm $<60$ atau push button ditekan maka tidak memenuhi standar normal rata-rata 70-90 orang pada umumnya. Secara otomatis mengaktifkan GPS dan pengiriman SMS yang berisi informasi koordinat Latitude dan Longtitude serta koordinat direct link pada google map.Pengujian dan pengamatan alat memiliki nilai rata - rata kesalahan sebesar 13.3\%. Rancangan alat ini diharapkan mampu mengirim informasi koordinat Latitude dan Longtitude serta direct link ke google maps melalui SMS dengan baik.
\end{abstract}

Kata Kunci : Arduino Nano, Sensor pulse, SIM808, Latitude dan Longtitude.

\section{PENDAHULUAN}

\subsection{Latar Belakang}

Sering kali pesawat mengalami kecelakaan saat mengudara dan terjatuh di laut, baik kecelakaan itu disebabkan oleh cuaca buruk, kerusakaan mesin, Human error atau faktor lain. Hal tersebut sering terjadi yang paling menjadi perhatian utama adalah pertolongan terhadap penumpang, secepat mungkin apapun pertolongan baik itu Helicopter atau kapal penyelamat sangat penting karena kondisi laut sangat berbeda dengan di darat apalagi ketika saat itu cuaca sedang buruk, penumpang tidak akan berada tetap karena arus akan membawanya dan bisa saja tenggelam.

Selama ini tim SAR dalam menentukan sumber informasi lokasi TKP melalui sumber informasi adanya musibah di dapat dari objeknya sendiri, yaitu objek transportasi seperti pesawat terbang atau kapal laut yang mengalami musibah melalui personal person yang memiliki Beacon dan mengaktifkan sinyal distress alert dari lokasi musibah.

Namun dalam pencarian korban hanya berdasar pada informasi objek jika kejadiannya pada korban atau penumpang tidak ada informasi spesifik detail lokasi korban tersebut, bilamana korban terpencar dikarenakan arus gelombang laut, badai dan cuaca yang buruk maka akan memperlambat atau mempersulit pencarian, untuk mempermudah pencarian korban diperlukan informasi spesifik lokasi untuk mempersingkat waktu dan parameter lokasi korban.

Informasi spesifik yang diperlukan oleh tim SAR untuk mempersingkat waktu dan parameter lokasi korban adalah alat bantu pemberitahuan lokasi korban yang lebih spesifik sehingga dapat memberi pertolongan secepat mungkin. Alat ini mempunyai dua pilihan fungsi yaitu Sensor Pulse detak jantung sebagai trigger ketika orang tersebut 
meninggal maka detak jantungnya berhenti maka alat tersebut memberi tanda kepada penerima melalui pemberitahuan lokasi latitude dan longtitude melalui SMS. Dan bisa diaktifkan GPS share location ketika keadaan darurat saat orang tersebut masih hidup dan membutuhkan pertolongan, Alat tersebut akan selalu menyala sesuai daya baterei sehingga penerima akan segera mengetahui lokasi kordinat korban dengan bantuan Peta laut dan Google Maps.

\subsection{Rumusan Masalah}

Permasalahan yang menjadi pembahasan dalam tugas akhir ini adalah bagaimana membuat alat yang bisa bekerja otomatis dan manual mengirimkan lokasi GPS Latitude dan Longtitude melalui SMS ke nomor penerima. Dengan berbasis Arduino dan GSM/GPS Module sebagai sistem operasinya dan sensor pulse sebagai trigger nya.

\subsection{Tujuan Penelitian}

Tujuan dari penelitian ini adalah merancang dan membuatan prototype sistem pemberitahuan lokasi darurat dari Arduino dan GSM/ GPS Module sebagai control unit, SEN-11574 sebagai sensor detak jantung dan handphone sebagai penampil lokasi kordinat latitude dan longtitude. Untuk menentukan kordinat latitude dan longtitude tim SAR memerlukan alat bantu lain berupa Peta atau Google Maps. Dengan adanya alat tersebut korban kecelakaan atau korban meninggal dapat teridentifikasi lokasinya sehingga Tim SAR dapat memberi pertolongan se-efektif mungkin.

\section{TINJAUAN PUSTAKA}

\subsection{Pencarian dan Penyelamatan}

SAR (search and rescue) adalah kegiatan dan usaha mencari, menolong, dan menyelamatkan jiwa manusia yang hilang atau dikhawatirkan hilang atau menghadapi bahaya dalam musibah-musibah seperti pelayaran, penerbangan, dan bencana. Istilah SAR telah digunakan secara internasional tak heran jika sudah sangat mendunia sehingga menjadi tidak asing bagi orang di belahan dunia manapun tidak terkecuali di Indonesia.

Operasi SAR dilaksanakan tidak hanya pada daerah dengan medan berat seperti di laut, hutan, gurun pasir, tetapi juga dilaksanakan di daerah perkotaan. Operasi SAR seharusnya dilakuan oleh personal yang memiliki ketrampilan dan teknik untuk tidak membahayakan tim penolongnya sendiri maupun korbannya. Operasi SAR dilaksanakan terhadap musibah penerbangan seperti pesawat jatuh, mendarat darurat dan lain-lain, sementara pada musibah pelayaran bila terjadi kapal tenggelam, terbakar, tabrakan, kandas dan lain-lain. Demikian juga terhadal adanya musibah lainnya seperti kebakaran, gedung runtuh dan lain-lain. Rangkaian dari siklus penanganan kedaruratan penanggulan bencana alam. Siklus tersebut terdiri dari pencegahan (mitigasi), kesiagaan (preparedness), tanggap darurat (response) dan pemulihan (recovery) dimana operasi SAR merupakan bagian dari tindakan dalam tanggap darurat.

\subsection{Arduino}

Arduino merupakan sebuah mikrokontroler dengan platform komputasi fisik (Physical Computing) open source sederhana. Yang dimaksud dengan platform komputasi fisik adalah sistem fisik yang interaktif dengan penggunaan software dan hardware yang dapat mendeteksi dan merespon situasi dan kondisi yang ada didunia nyata. Arduino juga didefinisikan sebagai sebuah platform elektronik yang open source, berbasis pada software dan hardware yang fleksibel dan mudah digunakan, yang ditujukan untuk pengguna dan setiap orang yang tertarik dalam membuat objek atau lingkungan interaktif.

\subsubsection{Arduino Nano v3}

Arduino Nano adalah salah satu papan pengembangan mikrokontroler yang berukuran kecil, lengkap dan mendukung penggunaan breadboard. Arduino Nano diciptakan dengan basis mikrokontroler ATmega328 (untuk Arduino Nano versi 3.x) atau ATmega 168 (untuk Arduino versi 2.x). 
Arduino Nano kurang lebih memiliki fungsi yang sama dengan Arduino Duemilanove, tetapi dalam paket yang berbeda. Arduino Nano tidak menyertakan colokan DC berjenis Barrel Jack, dan dihubungkan ke komputer menggunakan port USB Mini-B. Arduino Nano dirancang dan diproduksi oleh perusahaan Gravitech.

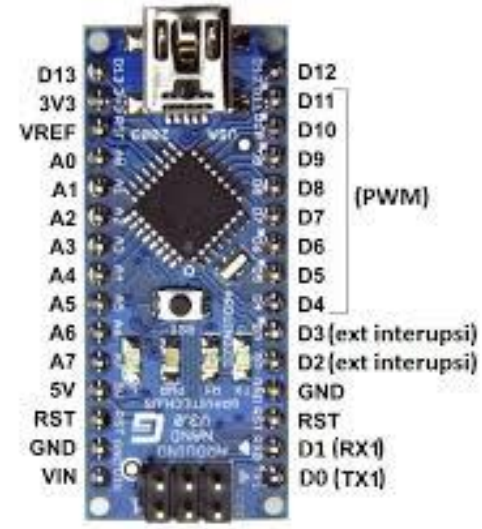

Gambar 1 Main board Arduino Nano

Tabel 1 Spesifikasi Arduino Nano v3

\begin{tabular}{|l|l|}
\hline Microcontroller & Atmel ATmega328 \\
\hline Operating Voltage (logic level) & $5 \mathrm{v}$ \\
\hline Input Voltage (recommended) & $7 \mathrm{v}-12 \mathrm{v}$ \\
\hline Input Voltage (limits) & $6 \mathrm{v}-20 \mathrm{v}$ \\
\hline Digital I/O Pins & 14 (of which 6 provide PWM output) \\
\hline Analog Input Pins & 8 \\
\hline DC Current per I/O Pin & $40 \mathrm{~mA}$ \\
\hline Flash Memory & $32 \mathrm{~KB}$ of which 2 KB used by bootloader \\
\hline SRAM & $2 \mathrm{~KB}$ \\
\hline EEPROM & $1 \mathrm{~KB}$ \\
\hline Clock Speed & $16 \mathrm{MHz}$ \\
\hline Dimensions & $0.73 " \times 1.70 "$ \\
\hline Length & $45 \mathrm{~mm}$ \\
\hline Width & $18 \mathrm{~mm}$ \\
\hline Weight & $5 \mathrm{~g}$ \\
\hline
\end{tabular}

\subsection{Arduino IDE}

Arduino IDE adalah sebuah sistem operasi yang digunakan secara khusus untuk perancangan program Arduino, meskipun sebenarnya Arduino bisa digunakan di sistem operasi yang lain.

Langkah awal penggunaan Arduino IDE adalah dengan melakukan instalasi terlebih dahulu. Untuk menjalankan software IDE ini, layaknya menjalankan sebuah aplikasi pada umumnya. Seperti halnya bahwa kelebihan Arduino adalah pada penggunaan IDE-nya yang mudah karena kesederhanaannya. Program di software Arduino sering disebut sebagai sketch.

Instruksi Arduino IDE Ada tiga bagian utama dalam bahasa pemrograman Arduino yaitu struktur, Variabel, Fungsi. Bagian struktur Arduino ini meliputi kerangka program, sintaks program, kontrol aliran program, dan operator.

\section{Kerangka program}

Kerangka program Arduino sangat sederhana, yaitu terdiri dari dua blok. Blok pertama adalah void setup(), dan blok kedua adalah void loop().

\section{Sintaks program}

Baik blok void setup(), void loop() maupun blok function harus diberi tanda kurung kurawal buka "\{" sebagai tanda awal program di blok itu dan kurung kurawal tutup ")" sebagai tanda akhir program. Tanda kurung kurawal buka dan kurung kurawal tutup tersebut juga digunakan pada blok kontrol program, seperti if, if-else, for-loop, whileloop, do-while-loop. Untuk menandai akhir sebuah baris kode program digunakan tanda titik koma ";" Kontrol Aliran Program Kontrol aliran program ini meliputi instruksiinstruksi yang digunakan untuk membuat percabangan dan perulangan. Instruksi percabangan diantaranya adalah if, if-else, switch case, break, continue, return dan goto. Sedangkan instruksi perulangan diantaranya adalah for-loop, while-loop, dowhile-loop.

\subsection{Modem GSM GPRS GPS SIM808}

Modem GSM GPRS GPS SIM808

Merupakan modul intregasi canggih yang dapat digunakan utuk komunikasi secara jaringan seluler (SMS, Voice Call, dan Internet), selain itu juga terdapat sensor lokasi A-GPS (indoor/outdoor) yang bisa bekomunikasi dengan satelit di dalam gedung ataupun di area terbuka. Fitur utama lainnya dari SIM 808 yaitu :

- Quad BAND GSM Frequency (GSM $850 \mathrm{MHz}$, EGSM 900MHz, DCS $1800 \mathrm{MHz}$, dan PCS $1900 \mathrm{MHz}$ ).

- PCI/SPI/SD Card Interface.

- RTC. 
- A Glonas GPS.

- Uplink/Downlink data GPRS up to 85,6 kbps.

- Accuracy GPS 0,05 m/s2 .

- Low Voltage Operating $(3,4 \mathrm{~V}-4,4 \mathrm{~V})$.

- Serial Connection (UART).

- Baudrate $1200 \mathrm{bps}$ up to $115200 \mathrm{bps}$.

GSM GPS Shield adalah salah satu perangkat atau modul yang dapat dihubungkan dengan Arduino. GSM Shield merupakan perangkat yang memungkinkan untuk melakukan pengontrolan perangkat output lain yang terhubung dngan arduino melalui internet dengan menggunakan jaringan GPRS. Jaringan GPRS ini dapat digunakan sebagai pengirim atau penerima pesan singkat (SMS) atau panggilan telepon, selain itu shield ini juga dapat berkomunikasi dengan board arduino dengan menggunakan AT Comand. Untuk dapat melakukan pengontrolan, pin RX yang terdapat pada shield dan arduino perlu dihubungkan, kemudian hal yang sama perlu dilakukan pada pin TX. GSM shield dapat beroperasi dengan arus dan tegangan yang diberikan dari board arduino.

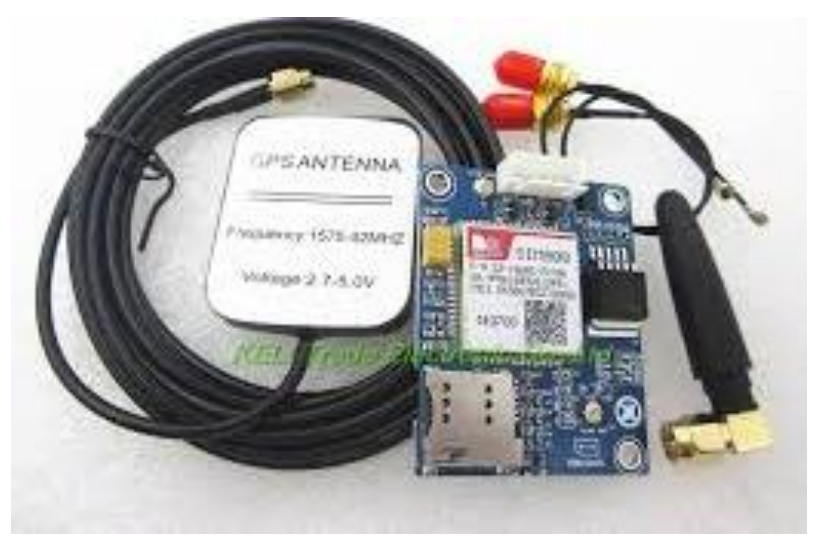

Gambar 2 SIM808 GSM GPS Shield

\subsection{GPS}

Sistem Pemosisi Global Global Positioning System (GPS) adalah sistem untuk menentukan letak di permukaan bumi dengan bantuan penyelarasan sinyal satelit. Sistem ini menggunakan 24 satelit yang mengirimkan sinyal gelombang mikro ke Bumi. Sinyal ini diterima oleh alat penerima di permukaan, dan digunakan untuk menentukanletak, kecepatan, arah, dan waktu.

\subsubsection{Latitude dan Longtitude}

Perlu di ketahui pula konversi derajat menit (') dan detik (") pada letak astronomis suatu tempat dalam satuan jarak ( $\mathrm{km}$ dan $\mathrm{m}$ ). Dalam pemakaian GPS sering didapatkan titik koordinat suatu posisi lokasi dalam bentuk Latitude (Lintang), Longitude (Bujur) atau Degree (Derajat). Dalam hal ini ada suatu formula yang digunakan untuk mengkonversi bilangan tersebut dari bentuk Degree Minute Second (DMS) menjadi Degree Decimal (DD), atau sebaliknya.

Konversi Degree Decimal (DD) menjadi Degree Minute Second (DMS): Bila diperoleh angka 109.036389 Longitude maka dapat diubah menjadi 109 derajat lalu angka dibelakang koma (contoh diatas: .036389) dikalikan bilangan desimal 60, (0.036389* 60 hasilnya 2.18334) tulis urutan kedua yaitu 2 menit, 'sisanya' angka dibelakang koma (contoh diatas: .18334) dikalikan lagi dengan bilangan desimal $60,(0.18334 * 60$ hasilnya 11.0004) tulis urutan ketiga yaitu 11 detik maka secara lengkap ditulis 109 derajat 2 menit 11 detik simboliknya $109^{\circ} 2 ' 11^{\prime \prime}$, hal ini berlaku juga pada Latitude. Selain itu nilai dari Latitude (Lintang) untuk bumi bagian utara (LU) di atas garis equator bernilai positif sedangkan untuk bagian selatan (LS) bernilai negatif. Begitu pula untuk Longitude (Bujur) untuk bumi bagian timur (BT) bernilai negatif sedangkan untuk bagian barat (BB) bernilai positif. Berikut ini adalah konversi Degree Minute Second (DMS) dalam ukuran jarak $10=111 \mathrm{~km}, 1^{\prime}=1.85$ $\mathrm{km}, \quad 1 "=30.9 \mathrm{~m}$. Hasil perhitungan jarak masih dalam satuan decimal degree (sesuai dengan format longlat yang dipakai) sehingga untuk menyesuaikannya perlu dikalikan dengan $111.319 \mathrm{~km}$ (1 derajat bumi = $111.319 \mathrm{~km})$.

\subsection{Google Maps}

Google maps dalam sistem ini hanya sebagai pendukung untuk mengetahui lokasi koordinat yang dikirimkan dapat terlihat di Peta. Karena sistem ini hanya mengirimkan latitude dan longtitude dengan bantuan 
google maps dapat terlihat lebih jelas arah utara dan selatan. Garis Bujur Yang perlu di ingat adalah angka depan pertama adalah ketinggian mengarah ke utara (+) mengara ke atas katulistiwa dari 0 ke 90 derajat di kutub utara. Dan garis khatulistiwa kearah kutub selatan, angka Bujur menunjukan angka minus (-) sebagai sumbu dibawah katulistiwa. Sedangkan horizontal bumi ditunjukan dengan angka kedua sebagai garis Lintang. Persinggungan antara kedua garis tersebut adalah menjadi titik lokasi koordinat atau petunjuk dari posisi yang diberikan perangkat GPS.

\subsection{Pulse Sensor}

Pulse Sensor Amped (atau disebut pulse sensor saja) pada dasarnya adalah sebuah photoplethysmograph PPG yang bekerja berdasarkan tanggapan terhadap perubahan intensitas cahaya relative.

Jika jumlah intensitas cahaya yang mengenai pulse sensor tetap makan nilai sinyal akan berada di sekitar 512 (nilai tengah rentang ADC 10 bit). Makin besar intensitas cahaya makin tinggi nilai ADC.

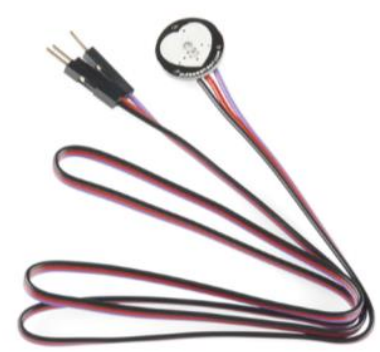

Gambar 3 Pulse sensor SEN 11574

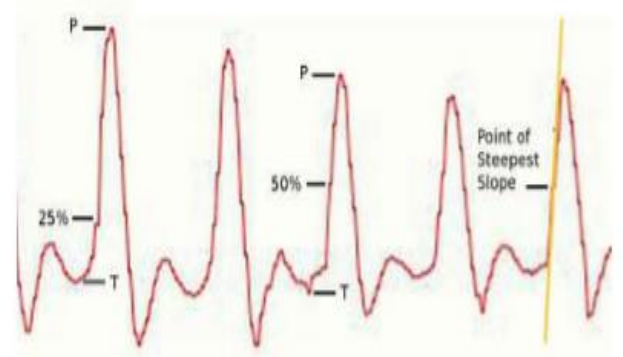

Gambar 4 Grafik Photoplethysmogram (PPG)

Sinyal yang dihasilkan oleh sensor menghasilkan gelombang yang dinamakan photoplethysmogram (PPG). PPG dalam dunia medis digunakan untuk pengukuran respiratory rate (pernafasan) dan heart rate (denyut jantung). Saat jantung memompa darah ke seluruh tubuh, setiap denyut yang terjadi disertai dengan munculnya gelombang pulsa seperti gelombang kejut yang merambat melalui arteri hingga ke lapisan kapiler tangan (jemari) tempat pulse sensor dipasang. Kecepatan darah mengalir lebih lambat daripada gelombang pulsa.

Penentuan jumlah denyut jantung per menit (BPM = beat per minute) dengan sensor ini dilakukan dengan membagi 60000 (dalam milidetik) nilai rata-rata dari sepuluh IBI (interbear interval) yang telah dilalui. IBI adalah selisih waktu antara satu titik dengan titik berikutnya dengan nilai titik tersebut adalah 50\% dari nilai $\mathrm{P}$ (puncak) dikurangi $\mathrm{T}$ (lembah) pada saat grafik terjadi kenaikan tajam. Jadi waktu yang diperlukan dalam melakukan pengukuran detak jantung dalam waktu 0.810 detik.

Perhitungan detak jantung dilakukan dengan menggunakan rumus Interbear Interval (IBI). IBI merupakan selang waktu pada detak jantung dalam mili detik dengan waktu momen sesaat dari jantung berdetak.

\subsection{Push Button}

Push button switch (saklar tombol tekan) adalah perangkat / saklar sederhana yang berfungsi untuk menghubungkan atau memutuskan aliran arus listrik dengan sistem kerja tekan unlock (tidak mengunci). Sistem kerja unlock disini berarti saklar akan bekerja sebagai device penghubung atau pemutus aliran arus listrik saat tombol ditekan, dan saat tombol tidak ditekan (dilepas), maka saklar akan kembali pada kondisi normal.

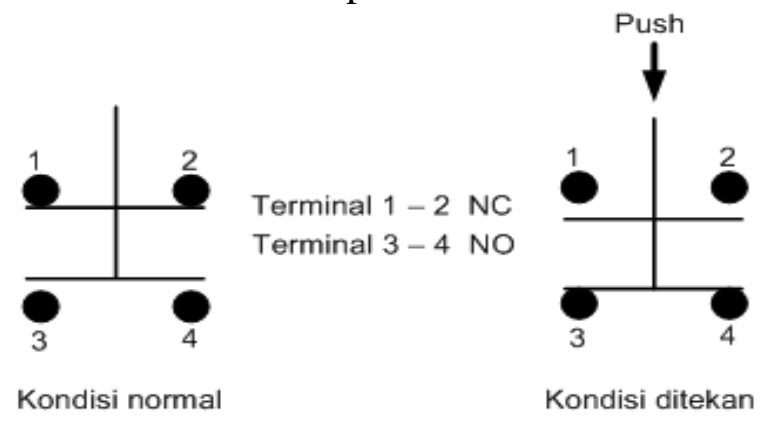

Gambar 5 Kondisi NC dan NO 
Karena sistem kerjanya yang unlock dan langsung berhubungan dengan operator, push button switch menjadi device paling utama yang biasa digunakan untuk memulai dan mengakhiri kerja mesin di industri. Secanggih apapun sebuah mesin bisa dipastikan sistem kerjanya tidak terlepas dari keberadaan sebuah saklar seperti push button switch atau perangkat lain yang sejenis yang bekerja mengatur pengkondisian On dan Off.

\subsection{LED}

Lampu LED atau kepanjangannya Light Emitting Diode adalah suatu lampu indikator dalam perangkat elektronika yang biasanya memiliki fungsi untuk menunjukkan status dari perangkat elektronika tersebut.

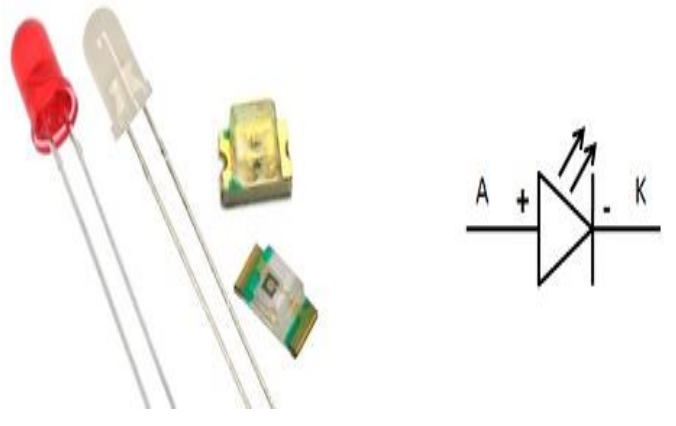

Gambar 6 Bentuk dan Simbol LED

Lampu LED terbuat dari plastik dan dioda semikonduktor yang dapat menyala apabila dialiri tegangan listrik rendah (sekitar 1.5 volt DC). Cara kerjanya pun hampir sama dengan Dioda yang memiliki dua kutub yaitu kutub Positif (P) dan Kutub Negatif (N).

\section{METODE PENELITIAN}

\subsection{Studi Literatur}

Permasalahan hilangnya kontak korban jatuhnya pesawat di perairan laut yang sering terjadi serta Informasi dari hilangnya kontak dengan pesawat pada pihak bandara. Dari perbedaan informasi tersebut, data Titik koordinat jatuhnya pesawat dan penumpang berbeda dari hasil pencarian di lapangan, sekitar 3 mil dari lokasi hilang kontak baru ditemukan kursi, tas penumpang dan bagianbagian pesawat. Namun korban tidak mempunyai informasi spesifik detail lokasi korban , untuk mempermudah pencarian langsung pada korban diperlukan informasi spesifik lokasi untuk mempersingkat waktu dan parameter lokasi korban. Sebagai tambahan fasilitas peralatan untuk membantu tim SAR dalam melakan pencarian, mikrokontroler Arduino dan SMS sebagai basis program alat serta sensor Denyut Nadi dan GPS sebagai alat pemberitahuan lokasi koordinat penumpang. Adapun literaturliteratur yang dipelajari antara lain Mikrokontroler Arduino Nano, Sensor Denyut Nadi, Rangkaian Catu daya, SIM808 GPS GSM, Push button, Led indicator dan pemograman Arduino IDE. Sedangkan perangkat lunak adalah program yang ditulis dan didownload pada chip arduino menggunakan software pemograman Arduino IDE yang berbasis bahasa java dengan media utama komputer.

Gambaran secara umum cara kerja Prototype Pemberitahuan Lokasi Kordinat Darurat Menggunakan GPS dan Pulse Sensor Berbasis Arduino dan SMS ini pengaturan Sensor Pulse terhadap level bpm detak jantung dengan program yang telah disesuaikan levelnya maka GPS otomatis akan mengirim SMS data Latitude dan Longtitude tersebut. Gambar 3.1 menunjukkan diagram blok sistem secara umum atau keseluruhan.

\subsection{Perancangan Alat}

Prototype Pemberitahuan Lokasi Kordinat Darurat Menggunakan GPS dan Pulse Sensor Berbasis Arduino dan SMS, terdiri dari perancangan hardware dan perancangan software. Perangkat keras terdiri dari rangkaian Arduino, SEN 11574 sebagai sensor detak jantung, Modul GSM GPS SIM808 dan handphone sebagai penampil lokasi kordinat latitude dan longtitude. Untuk menentukan kordinat latitude dan longtitude memerlukan alat bantu lain berupa Peta atau Google Maps.

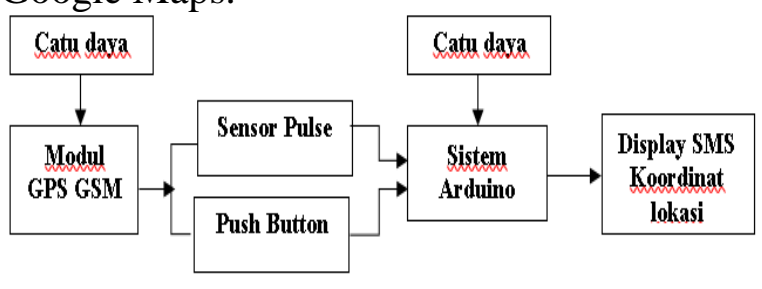

Gambar 7 Diagram Blok Sistem Alat 


\subsection{Perancangan Hardware}

Pada tahap ini dilakukan perancangan elektronik dan mekanik komponen yang digunakan pada rancangan alat ini diantaranya battery, Arduino, pulse sensor dan push button. Berikut penjelasan perancangan elektronik dan mekanik.

\subsubsection{Perancangan Mekanik}

Perancangan mekanik dalam pembuatan alat penelitian ini terdiri dari beberapa perangkat yaitu:

1. Case digunakan sebagai cover yang berbahan plastic ABS berukuran panjang $10 \mathrm{~cm}$ lebar 10 $\mathrm{cm}$ dan tinggi $4 \mathrm{~cm}$ berbentuk kubus

2. Arm Band digunakan untuk menopang alat untuk diikat pada lengan dengan bahan spoon dan Velcro perekat sensor berukuran panjang $30 \mathrm{~cm}$ dan lebar $5 \mathrm{~cm}$.

\subsubsection{Perancangan Elektronik}

Perangkat elektronik merupakan alat yang dibuat berdasarkan prinsip elektronika dengan sumber tenaga listrik arus lemah. Input dari sistem ini adalah denyut jantung yang diukur dengan menggunakan pulse sensor. Variable yang diukur (measurand) merupakan sinyal analog sehingga agar sinyal dapat diproses digunakan ADC dengan menggunakan mikrokontroler. Dalam perancangan dan pembuatan alat ini terdiri dari beberapa bagian yaitu :

1. Battery 3.7 volt digunakan sebagai sumber bagi SIM808 dan Arduino, dengan komponen pendukung DC Booster Converter. Rangkaiancatu daya sumber daya menggunakan battery 18650 LGHE4 dengan kapasitas $2500 \mathrm{mAh}$, tegangan sebesar 3.7 volt dan arus continous 2 - 20 ampere yang kemudian di converter menggunakan DC booster XL6009 4AMP dengan input voltage 3 - 32 volt, Output voltage 4 - 38 volt dan Arus rata-rata 3 Ampere yang berfungsi meningkatkan tegangan input menjadi tegangan output yang lebih tinggi.

2. Rangkaian pengendali untuk mengatur semua proses kerja alat menggunakan sistem Arduino Nano. Besar arus listrik yang diijinkan untuk melewati pin digital $\mathrm{I} / \mathrm{O}$ adalah $40 \mathrm{~mA}$. Pin digital I/O ini juga sudah dilengkapi dengan resistor pull-up sebesar 20-50 $\mathrm{k} \Omega$. Pada board Arduino Nano mempunyai 2 buah tegangan input yaitu melalui USB mini dan pin VCC direct . IC yang dipakai adalah ATmega328p dan IC CH340 sebagai downloader untuk memasukkan program pada IC ATmega328p yang dibutuhkan.

3. Push button digunakan untuk mengaktifkan GPS dan Pengiriman SMS secara manual. Rangkaian push button membutuhkan tegangan 5 volt dari output Arduino Nano dan kaki ground push button disambungkan dengan kaki kanan resistor $220 \mathrm{ohm}$ pada pin D6 dan kaki kiri resistor disambungkan resistor $10 \mathrm{k}$.

4. Pulse Sensor sebagai inputan trigger otomatis pengaktifan GPS dan pengiriman SMS pada Arduino Nano. Rangkaian pulse sensor menggunakan Light photo sensor APDS-9008 membutuhkan suplai tegangan 1.6 5.5 volt dan arus sebesar $4 \mathrm{~mA}$ dan Led. Yang kemudian ditambahkan dengan IC Op Amp MC6001 dengan suplai tegangan $1.8-6$ volt dan arus $2 \mathrm{~mA}$ sebagai penguat sinyal. Pin sensor pada pin Arduino A0 input, voltase dari $5 \mathrm{v}$ arduino dan pin ground tersambung pada pin ground rangkaian pulse sensor.

5. Modul SIM808 GPRS GPS sebagai Output GPS dan SMS. Modul rangkaian SIM808 menggunakan Jack power supply dengan tegangan 5-26 volt dan membutuhkan arus $2 \mathrm{~A}$. Antena pada board ini yang digunakan GSM antena dan GPS antena harus terpasang agar mendapatkan sinyal GSM dan GPS. 
Pin yang digunakan untuk menghubungkan dengan Arduino adalah TX RX dihubungkan silang dengan TX (0) RX (1) Arduino dan Ground juga tersambung.

6. Led sebagai indikator pulse sensor, pengaktifan GPS dan pengiriman SMS. Rangkaian led pin kaki + berada pada pin 4,5,7,8, dan 9 pada pin Arduino Nano berfungsi sebagai indikasi untuk pengaktifan GPS berwarna putih, indikasi bahwa SMS terkirim berwarna Led hijau dan denyut jantung jika berwarna kuning maka sensor sedang aktif mencari denyut sedangkan merah denyut diatas 120 bpm, biru dibawah 60 bpm.

\subsection{Perancangan Software}

Perancangan software untuk menjalankan hardware pada Arduino nano agar sesuai rancangan. Pemograman ini akan mengatur dan mendapatkan data dari beberapa komponen sebagai input dan output.

Dimulai dengan inisialisasi Pin-pin sensor, led dan RX TX yang di pakai, sensor aktif membaca nilai ADC dan terdapat 2 kondisi ketika BPM dibawah 60 atau push button ditekan maka akan mengaktifkan GPS dari SIM808. Setelah GPS ditemukan maka selanjutnya akan parsing data untuk isi SMS yang dikirimkan.

\section{PEMBAHASAN DAN ANALISA \\ 4.1 Pengujian Rangkaian Catu Daya}

Pengujian rangkaian catu daya dilakukan untuk memastikan sumber daya yang masuk ke rangkaian dapat digunakan alat untuk beroperasi karena catu daya memiliki peranan yang penting dalam kelangsungan kerja alat (hardware). Catu daya yang diperlukan rangkaian adalah tegangan $\mathrm{DC}+5 \mathrm{~V}$ yang dicatu dari baterai 3.7 $\mathrm{V}$ yang kemudian dihubungkan dengan Modul DC Booster converter yang akan menghasilkan output tegangan $+5 \mathrm{~V}$. Adapun data pengujian tegangan catu daya seperti diperlihatkan pada tabel di bawah ini.
Tabel 2 Pengujian Catu Daya

\begin{tabular}{|c|c|c|c|}
\hline No & Bagian & $\begin{array}{c}\text { Output } \\
\text { Tegangan } \\
\text { Tanpa } \\
\text { Beban }(\mathbf{V})\end{array}$ & $\begin{array}{c}\text { Output } \\
\text { Tegangan } \\
\text { dengan } \\
\text { Beban }(\mathbf{V})\end{array}$ \\
\hline 1 & $\begin{array}{c}\text { Baterai } \\
3.7 \mathrm{v}\end{array}$ & 3.76 & 3.74 \\
\hline 2 & Input & 3.76 & 3.73 \\
\hline 3 & Output & 5.11 & 5.09 \\
\hline 4 & Ground & 0 & 0 \\
\hline
\end{tabular}

Untuk mengetahui apakah rangkaian catu daya telah berfungsi atau belum digunakanlah lampu LED sebagai indikator power yang terdapat pada alat penelitian, ketika saklar dinyalakan maka LED indikator power menyala maka tegangan sudah mengalir pada rangkaian.

\subsection{Pengujian Rangkaian Mikrokontroller}

Mikrokontroller merupakan unit kontrol utama pada perancangan sistem ini, mikrokontroller yang digunakan dalam perancangan sistem ini menggunakan Arduino Nano karena ukuran nya praktis untuk diaplikasikan di pergelangan tangan dan mempunyai spesifikasi yang cukup dibutuhkan. Arduino ini digunakan untuk mengontrol pulse sensor, push button dan Modem GPS GSM SIM808.

Untuk pengujian board Arduino Nano dilakukan pengisian program terlebih dahulu menggunakan software Arduino IDE. Dengan mengcompile program ke Arduino Nano kita dapat mengetahui adanya error atau tidak. Untuk menjalankan program, caranya hubungkan langsung antara konputer dengan board Arduino Nano, lalu lihat pada Arduino IDE apakah program berhasil terupload. Bila berhasil, berarti Arduino Nano dapat digunakan. Setelah langkah di atas sudah selesai, dilakuakan pengecekan pin-pin analog dan digital pada board Arduino Nano. Peralatan-peralatan yang dibutuhkan untuk pengujian pin-pin digital yaitu PC, Arduinno Nano, Software Arduino IDE, LED. 
Dengan mengupload listing program di atas, maka LED akan menyala selama 1 detik dan kemudian padam selama satu detik demikian seterusnya. Maka pin-pin digital Arduino Nano dan compiling upload coding kedalam Arduino Nano dalam keadaan berfungsi.

\subsection{Pengujian Pulse Sensor}

Pulse sensor merupakan sensor utama pada perancangan sistem ini, mikrokontroller yang digunakan dalam perancangan sistem ini menggunakan Arduino Nano. Pulse sensor ini digunakan untuk mengontrol pengiriman sms dan modul GPS GSM SIM808.

Pengujian ini menggunakan tensimeter omron ini dengan alat penelitian dan nilai yang diambil pada tensimeter hanya nilai pulse. Pengukuran denyut jantung tensimeter ini kondisi tangan bebas untuk menggunakannya alat tensimeter di ikatkan pada pergelangan tangan kemudian setelah itu menekan tombol start pada monitor dan kabel manset di sudah terikat sempurna.

Tabel 3 Data analisis pengujian Alat penelitian dengan Tensimeter Omron.

\begin{tabular}{|c|c|c|c|c|c|}
\hline No & $\begin{array}{c}\text { Denyut } \\
\text { Jantung Alat } \\
\text { penelitian }\end{array}$ & $\begin{array}{c}\text { Denyut } \\
\text { Jantung } \\
\text { Tensimeter } \\
\text { Omron }\end{array}$ & Selisih & $\begin{array}{c}\text { Kesalahan } \\
\%\end{array}$ & Keterangan \\
\hline 1 & 85 & 86 & 1 & 1.16 & Rileks \\
\hline 2 & 96 & 86 & 10 & 11.6 & Bergerak \\
\hline 3 & 107 & 99 & 8 & 8.08 & Bernafas cepat \\
\hline 4 & 94 & 89 & 5 & 5.61 & Rileks \\
\hline 5 & 89 & 91 & 2 & 2.19 & Rileks \\
\hline $\mathbf{6}$ & 63 & 67 & 4 & 5.97 & \begin{tabular}{c} 
Istirahat \\
\hline 7
\end{tabular} \\
\hline $\mathbf{6 2}$ & 75 & 78 & 3 & 3.84 & Rileks \\
\hline $\mathbf{8}$ & 73 & 76 & 3 & 3.94 & $\begin{array}{c}\text { Kekurangan } \\
\text { Oksigen }\end{array}$ \\
\hline $\mathbf{9}$ & 55 & 60 & 5 & 8.33 & $\begin{array}{c}\text { Kekurangan } \\
\text { Oksigen }\end{array}$ \\
\hline $\mathbf{1 0}$ & \multicolumn{2}{|c|}{ Rata-rata } & & $\mathbf{5 . 5 3}$ & \\
\hline
\end{tabular}

Data hasil yang didapatkan dari Tabel 4.2 menunjukkan data hasil perbandingan pengukuran antara alat peneltian dengan tensimeter omron dan disertai dengan nilai selisih dan nilai persentase error. Berdasarkan hasil pengujian pulsesensor di atas pada faktanya setiap jantung tubuh manusia tidak memiliki denyut yang sama karena banyak faktor yang mempengaruhinya baik kondisi tubuh yang normal atau sedang kurang sehat sehingga pada setiap percobaan dan hasil bpm akan selalu berubah ubah. Dan dapat disimpulkan bahwa nilai sensor alat penelitian mempunyai rata-rata kesalahan sebesar $5.53 \%$.

\subsection{Pengujian SMS Menggunakan SIM808}

Pengujian modem GPS GSM Shield SIM808 bertujuan untuk mengetahui kinerja dan respon modem yang diberikan dalam mengirim perintah ketika pulse sensor mengalami pengkondisian dan penekanan push button.

Dalam pengujian ini diperlukan pengcodingan yang telah masuk dalam library DFROBOT808, pulse sensor sebagai trigger sms dan push button sebagai manual mengirim sms. Perintah yang diberikan akan mengirim sms yang berisi letak lokasi GPS dan Data Bpm Pulsesensor. Modem Sim808 ini dihubungkan dengan mikrokontroller RXTX menggunakan kabel komunikasi serial dan push button untuk menyalakan modem.

Tabel 4 Hasil Pengujian Pengiriman SMS dengan Pulse sensor

\begin{tabular}{|c|c|c|c|c|c|}
\hline No & $\begin{array}{c}\text { Pulse sensor } \\
\text { BPM }>150\end{array}$ & $\begin{array}{c}\text { Waktu } \\
\text { pengiriman } \\
\text { (WIB) }\end{array}$ & $\begin{array}{c}\text { Waktu } \\
\text { penerimaan } \\
\text { (WIB) }\end{array}$ & $\begin{array}{c}\text { Waktu } \\
\text { Selisih } \\
\text { (Menit) }\end{array}$ & Keterangan \\
\hline 1 & 154 & 23.33 & 23.35 & 2 & Terkirim Sesuai \\
\hline 2 & 205 & 23.52 & 23.53 & 1 & Terkirim Sesuai \\
\hline 3 & 171 & 00.27 & 00.27 & 0 & Terkirim Sesuai \\
\hline
\end{tabular}

Tabel 5 Hasil Pengujian Pengiriman SMS dengan Push Button

\begin{tabular}{|c|c|c|c|c|c|}
\hline No & Push Button & $\begin{array}{c}\text { Waktu } \\
\text { pengiriman } \\
\text { (WI) }\end{array}$ & $\begin{array}{c}\text { Waktu } \\
\text { penerimaan } \\
\text { (WB) }\end{array}$ & $\begin{array}{c}\text { Waktu } \\
\text { Selisih } \\
\text { (Menit) }\end{array}$ & Keterangan \\
\hline 1 & $\begin{array}{c}\text { Tidak } \\
\text { ditekan }\end{array}$ & 01.12 & 01.13 & 1 & $\begin{array}{c}\text { Tidak Terkirim } \\
\text { Sesuai }\end{array}$ \\
\hline 2 & $\begin{array}{c}\text { Ditekan } \\
\text { sekali }\end{array}$ & 01.23 & 01.23 & 0 & Terkirim Sesuai \\
\hline 3 & $\begin{array}{c}\text { Ditekan } \\
\text { duakali }\end{array}$ & 01.32 & 01.35 & 2 & Terkirim Sesuai \\
\hline
\end{tabular}

Dari hasil pengujian ini yang diperoleh maka data kecepatan pengiriman sms akan dipakai untuk mengetahui kecepatan respon dari kedua pengkondisian 
tersebut setidaknya ditambahkan delay 1 detik lebih lama dari lama respon sehingga arduino dapat memproses dengan efektif. Dan pushbutton hanya menerima pembacaan 1 kali tekan untuk mengaktifkan GPS dan pengiriman SMS.

\subsection{Pengujian dengan Data GPS SIM808}

Untuk mendapatkan data GPS, dapat menggunakan serial monitor pada Arduino IDE. Lalu Memasukan coding program ke Arduino Nano dan Mensetting wiring RX TX Arduino ke RX TX Modem SIM808 dan ground. Dalam pengujian ini diperlukan pengcodingan yang telah masuk dalam library dan sketch untuk pemanggilan program. Berdasarkan pada gambar 4.8 pengujian GPS pada alat penelitian didapatkan nilai Latitude, Longtitude, speed kph dan heading serta waktu. Namun dalam pengujian pada alat penelitian ini hanya mengambil nilai Latitude dan Longtitude saja untuk diambil.

Tabel 6 Pengujian GPS Data Latitude dan Longitude

\begin{tabular}{|c|c|c|c|c|c|}
\hline No & $\begin{array}{l}\text { Tempat yang } \\
\text { ditentukan }\end{array}$ & $\begin{array}{l}\text { Lokasi GPS } \\
\text { Googlemap } \\
\text { Smartphone }\end{array}$ & $\begin{array}{c}\text { Lokasi GPS } \\
\text { Alat } \\
\text { Penelitian }\end{array}$ & $\begin{array}{c}\text { Selisih } \\
\text { Latitude }\end{array}$ & $\begin{array}{c}\text { Selisih } \\
\text { Longtitude }\end{array}$ \\
\hline 1 & $\begin{array}{c}\text { Universitas } \\
\text { Muhammadiyah } \\
\text { Gresik }\end{array}$ & $\begin{array}{c}\text { LAT } \\
-7.1628730 \\
\text { LONG } \\
112.6226420\end{array}$ & $\begin{array}{c}\text { LAT } \\
-7.1628730 \\
\text { LONG } \\
112.6226420\end{array}$ & 0 & 0 \\
\hline 2 & $\begin{array}{l}\text { Mc Donald's } \\
\text { Gresik }\end{array}$ & $\begin{array}{c}\text { LAT } \\
-7.1515470 \\
\text { LONG } \\
112.6531230 \\
\end{array}$ & $\begin{array}{c}\text { LAT } \\
-7.1515470 \\
\text { LONG } \\
112.6531230 \\
\end{array}$ & 0 & 0 \\
\hline 3 & Satlantas Gresik & $\begin{array}{c}\text { LAT } \\
-7.1608390 \\
\text { LONG } \\
112.6156650\end{array}$ & $\begin{array}{c}\text { LAT } \\
-7.1608390 \\
\text { LONG } \\
112.6156650\end{array}$ & 0 & 0 \\
\hline
\end{tabular}

Dari data 1 sampai 3 yang telah di tentukan lokasinya melalui GPS pada google maps dan GPS alat penelitian lalu di ambillah 3 lokasi yang sama dengan alat GPS penelitian untuk mengetahui selisih data GPS kedua alat tersebut. Sehingga dapat di simpulkan bahwa GPS alat penelitian selisih nilai 0 dan persentase nilai error tidak ada sehingga akurat.

\subsection{Pengujian alat penelitian secara keseluruhan}

Pada penelitian ini didapatkan suatu alat yang dapat digunakan untuk memonitor detak jantung dan GPS berbasis interaksi mikrokontroler Arduino Nano dan SMS dengan interface ponsel melalui komunikasi GPS GSM SIM808. Alat ini terdiri dari beberapa komponen yaitu pulse sensor, Arduino Nano, GPS GSM SIM808 dan Push Button.

Pulse sensor dipakai untuk mengukur detak jantung per menit dan dan sebagai trigger untuk mencari GPS dan mengirim SMS. Arduino Nano berperan sebagai mikrokontroler yang digunakan untuk mengkonversi besaran listrik dari sensor menjadi besaran digital sehingga dapat diolah dengan rumus. Pemrograman alat penelitian ini dikerjakan pada Arduino IDE. Sebagai interface yang akan menampilkan hasil pengukuran sensor sesuai dengan output dari Arduino dengan komunikasi SIM808.

Pengujian yang dilakukan dengan menghubungkan Arduino ke rangkaian pulse sensor untuk mendapatkan denyut jantung pengguna sebagai trigger untuk mendapat lokasi GPS, rangkaian GPS GSM SIM808 untuk mencari GPS dan mengirim SMS lokasi GPS kepada penerima dan rangkaian push button digital sebagai input manual mengirim SMS GPS.

\begin{tabular}{|c|c|}
\hline \multicolumn{2}{|c|}{ 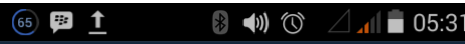 } \\
\hline $0822-347$ & $\oplus$ \\
\hline $\begin{array}{l}\text { Latitude : }-\underline{7.151604} \\
\text { Longitude : } \underline{112.653090} \\
\text { Wind Speed : } 0.98 \mathrm{kph} \\
\text { My Module Is Working. Raul } \\
\text { Gonzales Irawan. Try With } \\
\text { This Link. } \\
\text { http://www.latlong.net/ } \\
\underline{\text { Show-Latitude- }} \\
\underline{\text { Longitude.html }} \\
\underline{\text { http://maps.google.com/ }} \\
\text { maps?q=-7.151604,112.653 } \\
\text { 090 }\end{array}$ & \\
\hline SIM2 Nov 14 & \\
\hline
\end{tabular}

Gambar 7 Hasil Pengujian Alat keseluruhan berupa SMS.

Hasil pengujian alat seperti pada gambar 4.9. Dapat memberikan informasi berupa SMS kepada nomor tujuan yang sudah diatur dalam sistem Arduino Nano, yang berisi Latitude, Longtitude, Windspeed dan 
direct link ke web http//www. latlong.net dan maps.google.com.

Pengujian alat keseluruhan seperti pada tabel 4.6. dilakukan 15 kali percobaan, didapatkan 13 kali percobaan sesuai dan 2 kali percobaan tidak sesuai dengan perancangan pada kolom13 dan 14.

Tabel 4.6 Pengujian Alat Keseluruhan

\begin{tabular}{|c|c|c|c|c|c|}
\hline No & Denyut & Push Button & GPS & SMS & Keterangan \\
\hline $\mathbf{1}$ & 80 & Tidak ditekan & Mati & $\begin{array}{c}\text { Tidak } \\
\text { Mengirim }\end{array}$ & Sesuai \\
\hline $\mathbf{2}$ & 127 & Tidak ditekan & Mati & $\begin{array}{c}\text { Tidak } \\
\text { Mengirim }\end{array}$ & Sesuai \\
\hline $\mathbf{3}$ & 60 & Tidak ditekan & Hidup & Mengirim & Sesuai \\
\hline $\mathbf{4}$ & 155 & Tidak ditekan & Mati & $\begin{array}{c}\text { Tidak } \\
\text { Mengirim }\end{array}$ & Sesuai \\
\hline $\mathbf{5}$ & 76 & Ditekan & Hidup & Mengirim & Sesuai \\
\hline $\mathbf{6}$ & 160 & Ditekan & Hidup & Mengirim & Sesuai \\
\hline $\mathbf{7}$ & 64 & Ditekan & Hidup & Mengirim & Sesuai \\
\hline $\mathbf{8}$ & 134 & Ditekan & Hidup & Mengirim & Sesuai \\
\hline $\mathbf{9}$ & 87 & Tidak ditekan & Mati & $\begin{array}{c}\text { Tidak } \\
\text { Mengirim }\end{array}$ & Sesuai \\
\hline $\mathbf{1 0}$ & 58 & Tidak ditekan & Hidup & Mengirim & Sesuai \\
\hline $\mathbf{1 1}$ & 89 & Tidak ditekan & Mati & $\begin{array}{c}\text { Tidak } \\
\text { Mengirim }\end{array}$ & Sesuai \\
\hline $\mathbf{1 2}$ & 76 & Tidak ditekan & Mati & $\begin{array}{c}\text { Tidak } \\
\text { Mengirim }\end{array}$ & Sesuai \\
\hline $\mathbf{1 3}$ & 43 & Tidak ditekan & Hidup & Mengirim & Tidak Sesuai \\
\hline $\mathbf{1 4}$ & 33 & Tidak ditekan & Hidup & Mengirim & Tidak Sesuai \\
\hline $\mathbf{1 5}$ & $\mathbf{7 9}$ & Tidak ditekan & Mati & $\begin{array}{c}\text { Tidak } \\
\text { Mengirim }\end{array}$ & Sesuai \\
\hline
\end{tabular}

Nilai kesalahan dari percobaan tabel 4.6. adalah sebesar $13.3 \%$. Pada kolom no 1 , 2, 4, 9, 11, 12 dan 15 ketika denyut 80 bpm dan kondisi push button tidak ditekan maka GPS tidak aktif dan tidak mengirim SMS maka alat bekerja sesuai perintah program namun ketika Denyut dibawah 60 bpm seperti pada kolom no 3, 10, 13 dan 14 maka GPS otomatis aktif dan mengirim SMS dan juga ketika ketika push button ditekan seperti pada kolom no 5-8 maka GPS aktif dan mengirim SMS. Dapat disimpulkan bahwa alat penelitian ini dapat berfungsi dengan baik dan sesuai dengan perencanaan. Dalam kondisi $\mathrm{BPM}<60$, sebagai trigger untuk mengaktifkan gps dan mengirim sms. Dan Push button manual untuk mengaktifkan GPS dan mengirim SMS juga berfungsi dengan baik.

\section{PENUTUP}

\subsection{Kesimpulan}

Berdasarkan hasil penelitian dan pengujian Prototype Pemberitahuan Lokasi Kordinat Darurat Menggunakan GPS dan Pulse Sensor Berbasis Arduino dan SMS yang telah dilakukan, maka dapat menarik kesimpulan sebagai berikut:

1. Pada sensor denyut jantung ini, dapat membaca denyut jantung permenit dengan rata-rata kesalahan sebesar $5.53 \%$

2. Kondisi Objek jantung tiap menit akan berbeda setiap pengukuran maka akan mempengaruhi nilai sistolik, diastolik dan pulse sehingga nilai di monitor akan berubah-ubah sesuai kondisi psikis objek.

3. Nilai pada denyut jantung tidak selalu dibawah atau diatas sistolik dan diastolik.

4. Nilai denyut jantung berubah-ubah tidak selalu sama dengan tiap pengukuran dikarenakan kondisi psikis objek akan selalu berubah-ubah setiap menitnya.

5. Pada sensor denyut nadi ini penempatan posisi sensor harus menempel sebaik mungkin pada pergelangan tangan agar nilai bpm stabil.

6. Data pada GPS tidak dapat diambil ketika posisi alat tersebut pada keadaan offline dan tidak ada sinyal dari provider simcard.

7. GPS alat penelitian memiliki nilai selisih 0 dan persentase nilai error tidak ada sehingga akurat.

8. Sensor denyut jantung ini, ketika bpm $<60$ akan mengaktifkan GPS dan pengiriman SMS. Setelah itu kembali membaca sensor kembali. Sehingga tidak terjadi penumpukan perintah.

9. Pushbutton hanya menerima pembacaan 1 kali tekan untuk mengaktifkan GPS dan pengiriman SMS.

10. Pada pengujian keseluruhan alat penelitian ini memiliki nilai kesalahan sebesar $13.3 \%$ 
11. Hasil alat penelitian ini dapat bekerja sesuai standar denyut jantung pada umum nya.

\subsection{Saran}

Untuk pengembangan lebih lanjut maka penulis memberikan saran yang sangat bermafaat dan dapat membantu mengembangkan alat yang sudah ada untuk masa yang akan datang, yaitu :

1. Penambahan beberapa sensor pada alat akan bisa lebih membantu untuk monitoring kondisi seseorang ketika orang tersebut mengalami kecelakaan, supaya tingkat keberhasilan lebih bagus.

2. Bentuk alat semakin kecil dan praktis akan sangat membantu pergerakan.

\section{DAFTAR PUSTAKA}

[1.] Hanofridho, F.M 2011. "Sistem Keamanan Sepeda Motor Berbasis GPS”. Sistem Komputer Fakultas Ilmu Komputer Universitas Gunadarma: Depok.

[2.] Wijaya, P.S. dan Sukiswo. 2010. "Alat Pelacak Lokasi Berbasis GPS Via Komunikasi Seluler". Teknik Elektro Fakultas Teknik Universitas Diponegoro : Semarang.

[3.] Galuh, W.W dan Arkhan, S. 2013 “Alat Pengukur Detak Jantung Menggunakan Pulse Sensor Berbasis Arduino Uno R3 Yang Diintegrasikan Dengan Bluetooth" . Teknik Elektro Fakultas Teknik Universitas Diponegoro : Semarang.

[4.] Septiani, D.A. 2015 "Perancangan Alat Pemantau Kondisi Kesehatan Manusia". Teknik Elektro Fakultas Teknik Universitas Negeri Semarang: Semarang.

[5.] Alimudin, Rudi. 2012 "Prototipe Sistem Pendeteksi Dini Kebakaran dengan SMS Sebagai Media Informasi Berbasis Mikrokontroler". Teknik Informatika, STMIK LPKIA: Bandung.

[6.] Usuman, Ilona dan Ardhi, Hasmi. 2010 “ Sistem Pendektasi Suhu dan
Asap pada Ruangan Tertutup Memanfaatkan Sensor LM35 dan Sensor AF30". Laboratorium Elektronika dan Instrumentasi, Fakultas Matematika dan Ilmu Pengetahuan Alam, Universitas Gadjah Mada: Malang.

[7.] Pradita. Rafi. 2013. “Pengaturan Sistem Keamanan dan Pemantauan Lokasi Mobil Dengan Fasilitas SMS”. Universitas Brawijaya : Malang.

[8.] Kadir, Abdul. 2013. Panduan Praktis Mempelajari Aplikasi Mikrokontroler dan Pemrogramannya menggunakan Arduino. Andi Offset: Yogyakarta.

[9.] Pearce, Evelyn. 2007. Anatomy and Physiology for Paramedics. Gramedia, Jakarta.

[10.] Target heart rate average http://www.heart.org/HEARTORG/He althy-

Living/PhysicalActivity/FitnessBasics/ Target-Heart-Rates_UCM_434341Article.jsp\#.WkpdwS5SBPY diakses pada 28 September 2017.

[11.] Project dan coding http://www.pulsesensor.com/gettingSt arted diakses pada 17 Juni 2017

[12.] Data sheet Modul SIM 900 http://www.famosastudio.com/icomsat -gsm- gprs-shield diakses pada 17 Juni 2017.

[13.] Sistem Komunikasi tim SAR http://www.basarnas.go.id/halaman/200116-sistem-komunikasi-sar diakses pada 17 Juni 2017.

[14.] Data sheet dan specification http://simcom.ee/modules/gsmgprs/sim808/ diakses pada 17 Juni 2017.

[15.] Pengertian GPS https://id.wikipedia.org/wiki/Sistem_P emosisi_Global diakses pada 17 Juni 2017. 